水バインダを用いたファインセラミックスの凍結圧縮成形

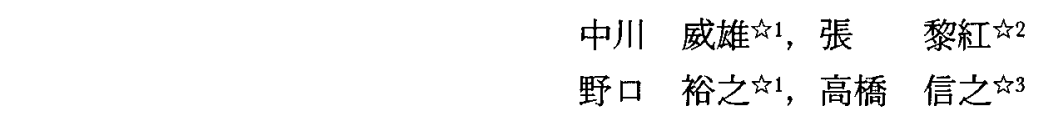

的東京大学生産技術研究所, 于106 港区六本木7-22-1.

江2 東京大学大学院, 矛106 港区六本木7-22-1.

的3 金型研究所, 干105 港区浜松町1-15-5 コープ浜松町502

\title{
Freeze Compression Molding of Fine Ceramics Powder by Using Water Binder
}

\author{
Takeo Nakagawa ${ }^{\text {\} 1 } \text {, Lihong Zhang }{ }^{\grave{2} 2}$ \\ Hiroyuki Noguchi ${ }^{2}$ and Nobuyuki Takahashi ${ }^{2} 3$
}

Institute of Industrial Science, University of Tokyo, 22-1 Roppongi 7 Chome Minato-ku Tokyo 106.
$t^{2}$ University of Tokyo, Graduate School., 22-1 Roppongi 7 Chome Minato-ku Tokyo 106.
Institute of Molds and Dies, 502 Corp Hamamatsucho 1-15-5 Hamamatsucho Minato-ku Tokyo 105.

Received October 18, 1991

To solve a problem that an extremely long debinding time is required before sintering in case of the ceramics powder compression molding process, the water binder is used for its easy debinding property in stead of polyner or wax binder. The shape fixing is done by freezing the binding water in the die cavity after compression forming. The vacuum freeze drying is applied for removing the water binder in order to prevent the cracking by the shrinkage of formed powder. It is proved by the experiment that flowability can be improved effectively and samples which have complex shape can be formed easily.

\section{1 緒 言}

構造用ファインセラミックスを機械部品として活 用する場合，先ず第 1 に原料のファインセラミック ス粉末の複雑形状体を高精度に成形することが必要 となる.しかも，工業部品として広く普及させるに は,この成形が大量に安価に行わなければならない. プラスチックスの成形と同様な手法である粉末射出 成形法は，まさにこれに応える形で出現したもので， 構造用ファインセラミックス成形における画期的量 産手段となった。䓨化珃素セラミックスの自動車用 ターボチャージャーのロータが粉末射出成形法で製 造されるようになって以来，すでに数多くのファイ ンセラミックスの機械部品が生産され, ファインセ ラミックス普及のために大きな貢献をしてきた ${ }^{\prime}$.

しかし，この粉末射出成形とて万能ではない。小 物部品には適用できるが, 厚肉の大物部品には不適 とされている.その理由は, 射出成形のために多量
に混入した有機バインダは, 後の脱バインダ工程で 除去されるものの，厚肉成形品では脱バインダが困 難であるためである. 脱バインダ工程では成形体を 加熱し，有機バインダを気化するが，内部での気化 は成形体を破損することとなるため, 成形体表面よ り気化せざるを得ない，そのため，昇温速度を極め て遅くしなければならず,これが脱バインダ工程が 長時間を要する原因となる。特に成形品の肉厚が増 すに従って，加速的に脱バインダ時間が増え，さら に脱バインダによる不良が発生する確率も高くなる ので, 実際上粉末射出成形は適用不可能といわれて いる ${ }^{2)}$.

最近この問題を解決するために, バインダを溶媒 で溶かし出したり，光で分解する脱バインダなど種 々の方法が考えられている ${ }^{31}$. 本研究は, 水バイン ダを用いることにより，この脱バインダ工程の問題 を解決することを試みたものである ${ }^{4,5)}$. 

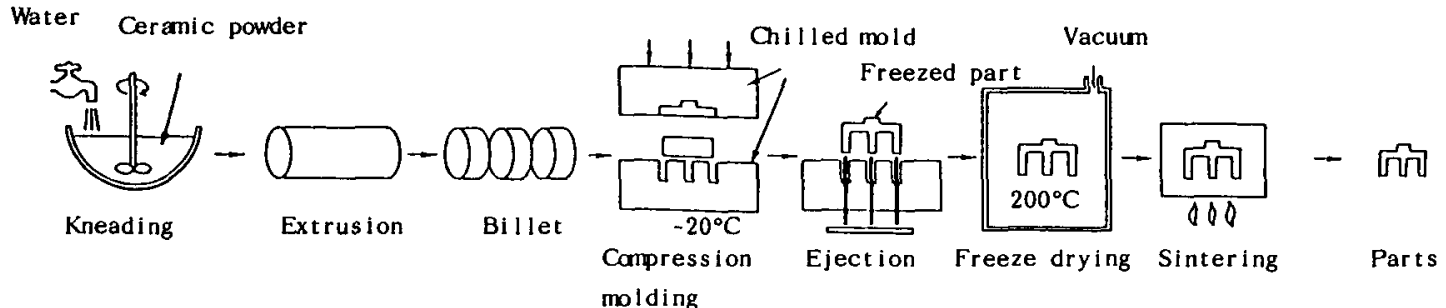

Fig.1 Process for freeze campression molding.

\section{2 水バインダ凍結圧縮法}

本法は射出成形と同じように粉末を圧樎して流動 させて成形することを前提とするが，先ず粉末に流 動性を与えるため水を添加する．水の添加は陶磁器 成形における原料である粘土に水を加えて粘性を得 るところからの発想である，加えた水は压縮成形後 に乾燥工程により容易に除去できる。この成形方法 で解決すべき主な問題点として, 先ず次の 3 点があ げられる.

(1) 粘性の少ない水を添加することによって十分 な流動性を得ることができるかどうか.

(2) たとえ流動性が得られても，それを型から離 型できるかどうか.

(3) 型から排出された成形体が乾熉中に收縮割れ を起こさないかどうか.

(1)の流動性に関しては，予備的な実験により十分 な流動性が存在することが確かめられた。また(2)の 離型の問題に関しては, 複雑形状の場合ピンによる 押出しを行わざるを得ない。そこで成形品を冷却し バインダとして使用した水分を凍結して固化し，固 体として取出す凍結法を採用することとした。固体 化時の水の膨張によって生ずる問題は, 後で検討す るものとする。(3)の乾燥収縮割れについては，凍結 状態のまま体積変化を行わない水分を异華する凍結 真空乾燥によるものとした. また, 乾燥後の保形性 については, 極く少量の有機バインダを混入して破 損を防ぐこととした.

以上の考察により，水バインダを用いたファイン セラミックスの凍結圧縮成形法ではFig.1 のような 工程が考えられた。ここで成形用ビレットの準備は, 陶磁器製造と同じく, 予備押出しにより棒材成形し,
切断して一定量を持つビレットを準備する．刎論予 借押出しと圧縮成形を一体化することも可能である。 その際，スクリューやプランジャタイプの押出しと 組合せるが, その時は押出し工具等の摩耗の問題を 解決しなければならない. 水バインダを含む粉末ビ レットは次の工程で, 流動を伴った玨縮成形が行わ れ椱雑形状を得る。ビレットは予め椧却されており， 金型は一 15〜20に冷却されているため，成形と同 時に凍結固化がはじまる，ある程度または完全に固 化した階段で成形体は押出しピンで取出される. 取 り出される成形体は凍結状態のまま真空乾燥機に入 れられる。水分が除去された嘲燥成形体は焼成炬に て焼成されファインセラミックス部品が得られる.

\section{3 流動性確認実験}

本成形技術を確立するため, 先ず水の添加量とつ アインセラミックス粉末の流動性を確認する実験を 行った. 実験に使用した粉末はアルミナ粉末であり， 各実験毎に使用したアルミナ粉末は異なるが, それ らの粉末の諸元をTable 1 に示す.

流動性試験はFig. 2の単純な押出し工具と, Fig. 3 のような割円断面をもつうず巻き状押出し工具を用 いて行った. 前者の工具では主として押出された 3 $\phi の$ 粉末の外観を観察することにより成形性を評価 し, 後者の工具では流動性を評価した。

これらの押出し実験は油圧プレスを用いて行った が，押出しの状況をPhoto. 1 に示す. なおこれらの 実験では水以外の結合材は含まれていない，押出さ れた成形体の外観状況をPhoto. 2 に示すが, 水分が 少なすぎても多すぎても不適であることが分かる.

Table 1. Specification of $\mathrm{Al}_{2} \mathrm{O}_{3}$ powder for molding test.

\begin{tabular}{ccccc}
\hline $\mathrm{Al}_{2} \mathrm{O}_{3}$ powder & $\begin{array}{c}\text { Average particle } \\
\text { size }(\mu \mathrm{m})\end{array}$ & $\begin{array}{c}\text { Specific surface } \\
\text { area }\left(\mathrm{m}^{2} / \mathrm{g}\right)\end{array}$ & $\begin{array}{c}\text { Purity } \\
(\%)\end{array}$ & $\begin{array}{c}\text { True density } \\
\left(\mathrm{g} / \mathrm{cm}^{3}\right)\end{array}$ \\
\hline AL-160SG(Showa Denkou) & 0.6 & 7.0 & 99.9 & 3.91 \\
TM5 (Ta imei Chemicals) & 0.2 & 7.0 & 99.9 & 3.98 \\
\hline
\end{tabular}


この例では水分 $20 \mathrm{wt} \%$ に良好な条件が存在するよう に見受けられた．20wt％は体積で50vol\%に相当し， この値は一般の粉末射出成形やスリップキャスティ ングに近い值であり, 空孔はほぼ水分で埋められて いると考えてよいと思われる. 実際の圧縮成形は密 閉型を使用し, 密度もかなり高いと考えられるので, この值よりかなり少ない水分の添加量で十分良好な 成形体が得られると考えられる.

Fig. 4 はうず巻き状試験片による流動試験結果で ある. 実験は室温下で, プランジャー圧力 $210 \mathrm{~kg} /$

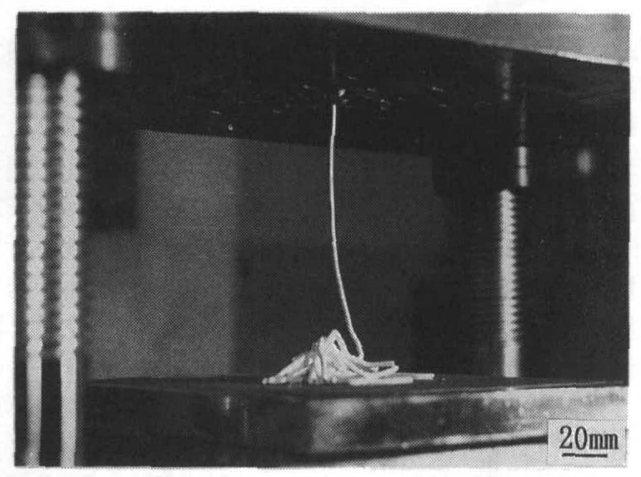

Photo.1 Extruding test $\mathrm{Al}_{2} \mathrm{O}_{3}$ powder.

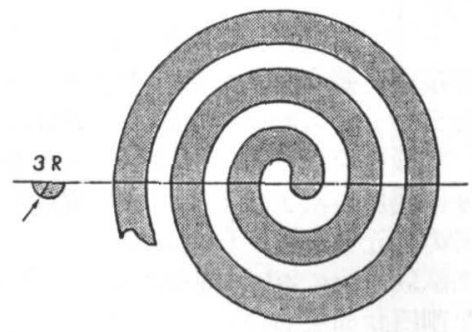

Fig.3 Flow pattern.

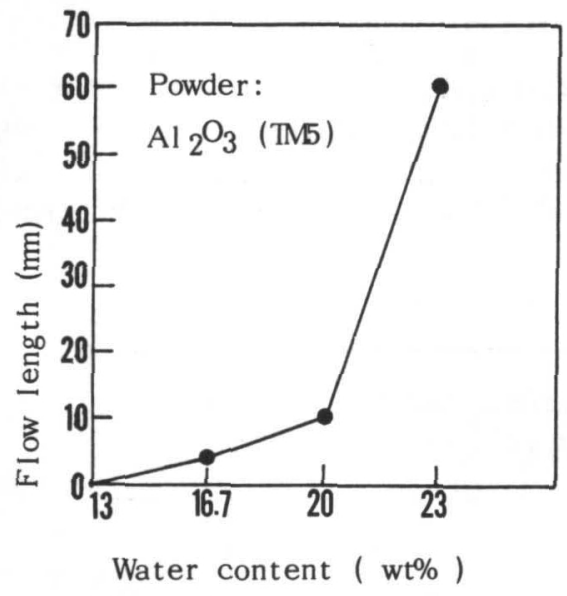

Fig.4 Results of flow test.

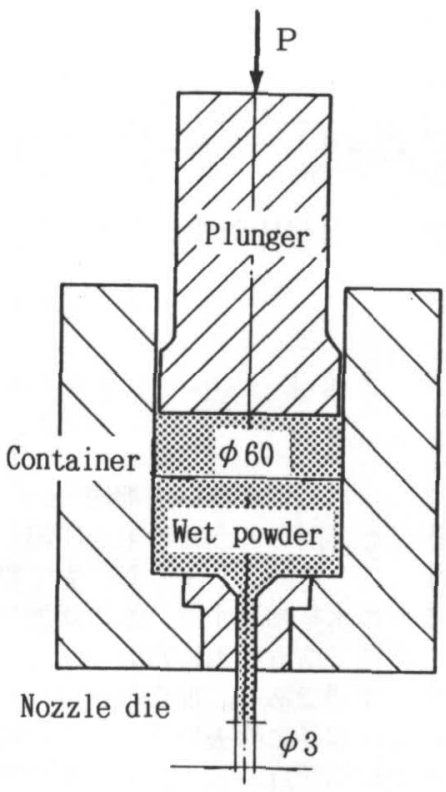

Fig.2 Extrusion tool.

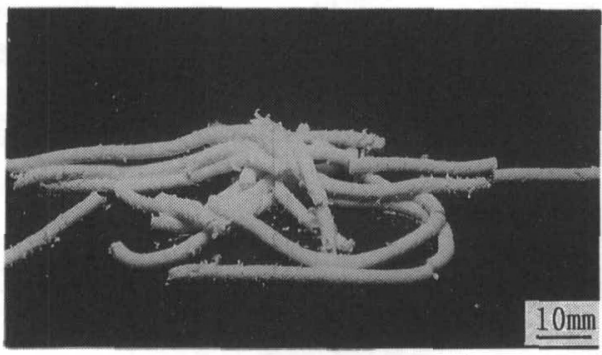

a) $16.7 \mathrm{wt} \%(44.0 \mathrm{vol} \%)$

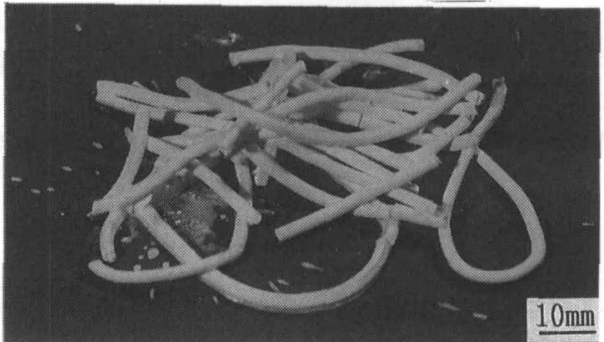

b) $20 \mathrm{wt} \%(49.4 \mathrm{vol} \%)$

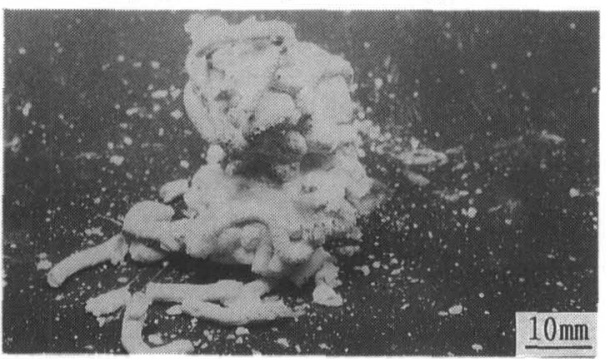

c) $23 \mathrm{wt} \%(53.8 \mathrm{vol} \%)$

Photo.2 Appearances of $3 \phi$ extruded $\mathrm{Al}_{2} \mathrm{O}_{3}$ powder . 
$\mathrm{cm}^{2}$, ノズル径 $3 \mathrm{~mm}$ で行われたが，水16.7wt\%で4cm， 20wt\%で10cmの流動長が得られている．23wt\%では 急に流動性が増すことが分かった。この実験で水16. $7 \mathrm{wt} \%$ で流動長が4cmであることは流動性からみる とより有利な圧縮成形では金型のかなり細いすき間 にも十分流動し得ることを意味する。

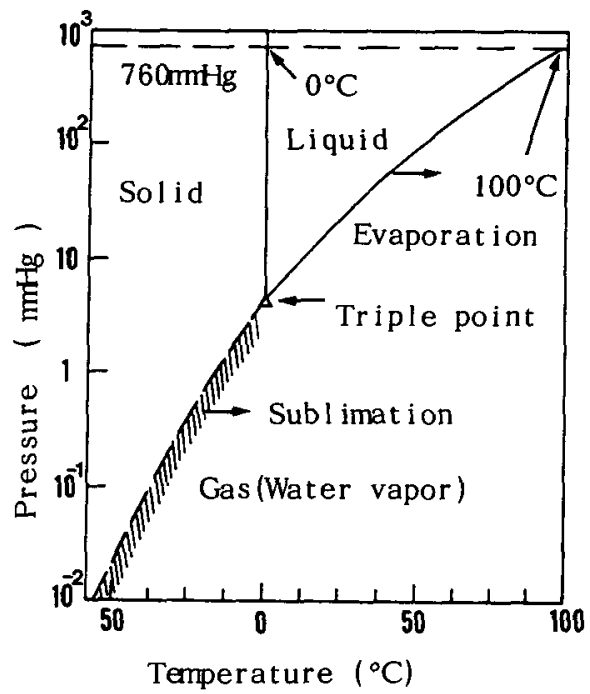

Fig. 5 Phase diagram of water.

\section{4 凍結真空乾燥実娩}

Fig. 5 に水の状態図を示す. 水の三重点以下の圧 力では水は昇華により直接水蒸気となる. 凍結真空 乾燥を実際に行ってみるため，40gのアルミナ粉に 水を添加した単軸圧縮成形体を作成し，加圧状態で 凍結させ，その後乾焻状態を調べた. Table 2に使 用した凍結真空乾燥機の仕様を示す。

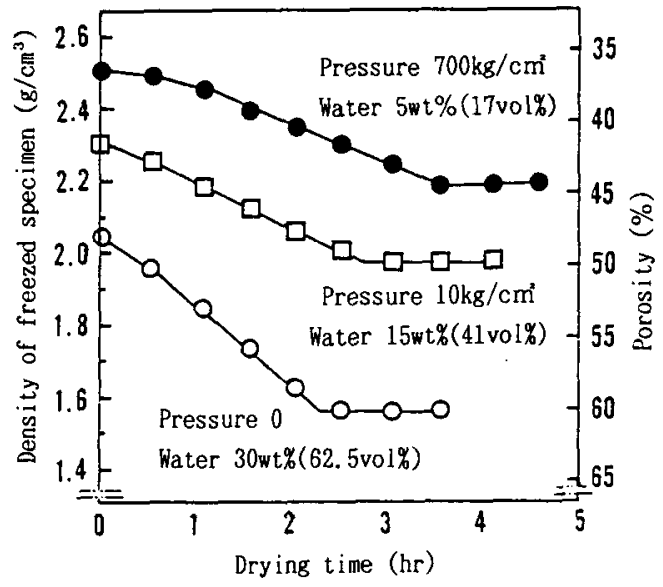

Fig.6 Relation between densit of freege drying samples and drying time in freeze drying process.
Table 2 Specification of freeze drying equipment

\begin{tabular}{cl}
\hline Type & DP-31 ( Yamato ) \\
\hline Heating & Direct form \\
\hline Temperature & $40 \sim 240^{\circ} \mathrm{C} \pm 1.5 \mathrm{C}$ \\
\hline Vacuum & $760 \sim 1$ Toor \\
\hline Heater & $1.1 \mathrm{kw}$ \\
\hline Volume capacity & $300 \times 300 \times 300 \mathrm{~mm}$ \\
\hline
\end{tabular}

Fig. 6 に乾燥温度を $80^{\circ} \mathrm{C}$ にした時の乾燥時間と密 度との関係を示す。密度低下は水分除去を示し，一 定值となった点が乾燥䅂了状態である。加圧成形体 の乾燥で，水分量の違いにより乾燥開始時間に差が あるが，乾煤開始後はいずれの水分量においても $2.1 \mathrm{~g} / \mathrm{hr}$ であった. 低圧圧縮成形体で㲦燥開始点が 早いのは，成形体に存在する空孔量が多いため，そ の分表面積が大きかったためである.

次に乾燥時間の短縮をはかるため, 乾燥温度を上 げる実験を行った。Fig. 7 に結果を示す如く, 温度

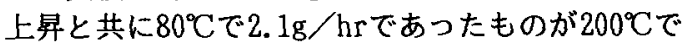
は6. $4 \mathrm{~g} / \mathrm{hr}$ まで乾燥速度が上昇した. なおこれらの 乾燥実験では，乾燥収縮等によるクラック発生は諗 められなかった。

\section{5 凍結圧縮成形実験}

以上の基礎実験の結果をもとに以下に示す2つの 成形実験を行った。これは成形体の凍結後の離型性

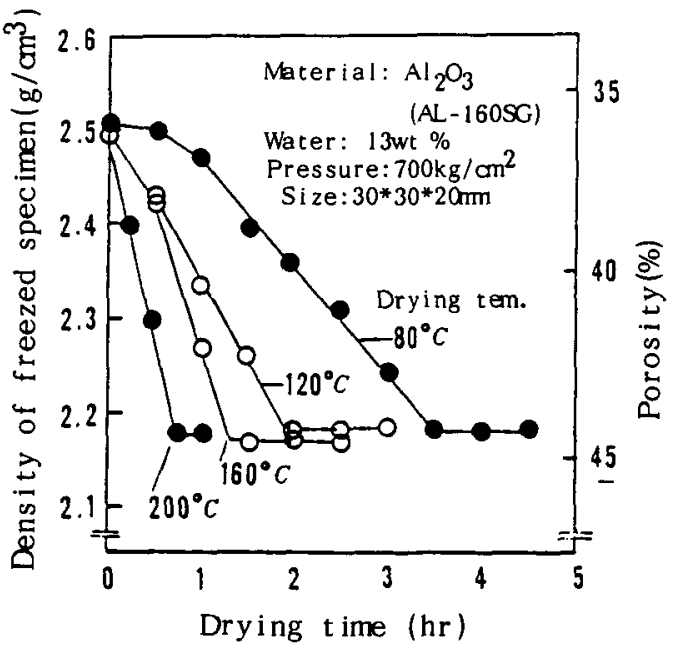

Fig.7 Relation between density of freeze drying samples and drying time. 


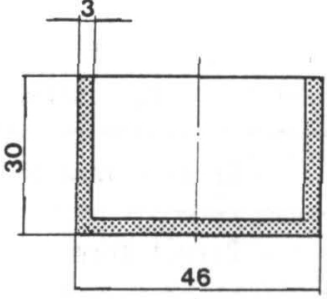

a) Cross section of molded specimen.

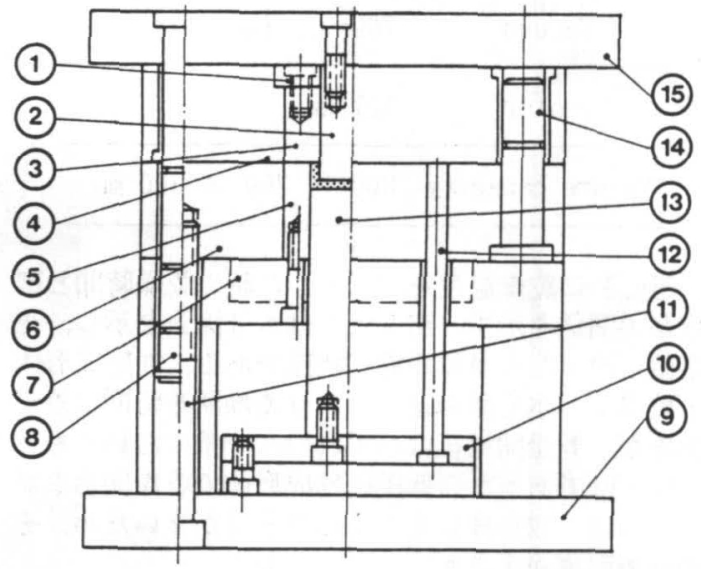

b) Shaping dies.

Fig. 8 Box molded specimen and shaping dies.

1)Block holder,2)Upper punch,3)Block, 4)Clamping plate,5)Block,6)Mbvable die, 7)Backing plate, 8)Guide pin,9)Base, 10)Clamping plate of return pin,11)Punch set, 12)Return pin, 13)Lower punch, 14)Guide pin, 15)Base of movable die.

を調べることを主眼として行ったものである.

Table 3 に使用した成形機と冷凍機の諸元を示す.

\section{1 箱形の成形}

成形体および成形型の構造をFig. 8 に示す. 成形 型には冷却用配管を施し, あらかじめ $-15^{\circ} \mathrm{C} に$ 冷却

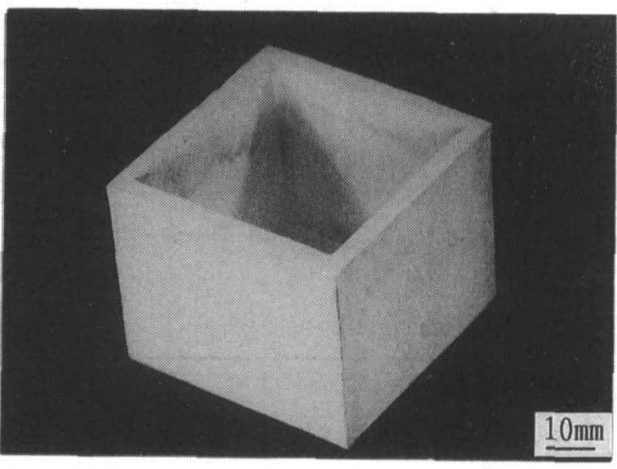

Photo.3 Sample molded specimen (green $\left.\mathrm{Al}_{2} \mathrm{O}_{3} 46 \times 46 \times 30 \mathrm{~mm}, \mathrm{t}=3 \mathrm{~mm}\right)$.
Table 3 Specification of freeze injection molding device.

\begin{tabular}{|c|c|c|}
\hline \multicolumn{2}{|c|}{ Plunger pressure $(\max )$} & $209 \mathrm{~kg} / \mathrm{cm} 2$ \\
\hline \multicolumn{2}{|l|}{ Injection pressure } & 2.8 ton \\
\hline \multirow{2}{*}{ Injection velocity } & \multicolumn{2}{|c|}{$\max 288 \mathrm{~mm} / \mathrm{sec}$} \\
\hline & $\min$ & $57 \mathrm{~mm} / \mathrm{sec}$ \\
\hline \multicolumn{2}{|c|}{ Clamping pressure (max) } & $84.8 \mathrm{~kg} / \mathrm{cm} 2$ \\
\hline \multicolumn{2}{|c|}{ Setting arza of molding } & $625 \mathrm{~cm} 2$ \\
\hline \multirow{2}{*}{\multicolumn{2}{|c|}{ Molding snatch velocity }} & $\max 15 \mathrm{~mm} / \mathrm{sec}$ \\
\hline & & $\min 3 \mathrm{~mm} / \mathrm{sec}$ \\
\hline \multicolumn{2}{|c|}{ Brine cooler(Kopurand) } & $2.2 \mathrm{kw}$ \\
\hline \multicolumn{2}{|l|}{ Refrigerant of pomp } & $F \operatorname{lon}(R-11)$ \\
\hline \multicolumn{2}{|l|}{ Refrigerant of dies } & Flon $(\mathrm{R}-11)$ \\
\hline \multicolumn{3}{|c|}{ Cooling minimum temperature } \\
\hline
\end{tabular}

した金型に水バインダ $18 \mathrm{wt} \%$ を含む一定量のアルミ ナ粉末を圧縮成形した.この時, ビレットは混練後 手で固めただけのものである. 圧縮成形体を2分間 保持して取出した. Photo. 3 にその成形体の写真を 示す. 金型材に焼入れを行わなかったため, 型材の 表面が少々削られ，わずかではあるが型材よりの鉄 粉が表面に付着しているのが認められた。

\section{2 フィン付き形状の成形}

より大寸法でより複雑な形状の成形を試みるため にフィン付き形状の成形を行った. 成形体外寸法は $108 \mathrm{~mm}$, 高さ $25 \mathrm{~mm}$, 厚さ $2.5 \mathrm{~mm}$ の個のフィン部をも つ. 通常のプラスチックの射出成形においても必ず しも容易とは言えない形状である. 成形後の突出し

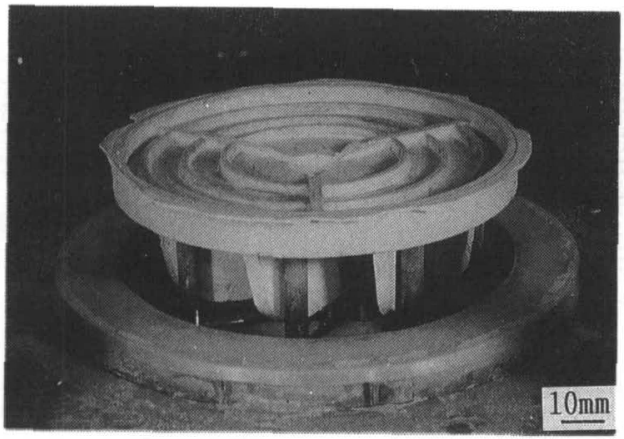

Photo.4 Molded specimen with complicated shape after ejecting. 
は6申のピン9本でフィン部を押出す構造をしている. また金型の表面は耐摩耗性と表面粗さを少なくする ため硬質クロムメッキを施している. 粉末および水 添加量等は前記条件と同一である. ただし, 今回の 金型には冷却装置がついていないため, 型の周囲を ドライアイスでー $12^{\circ} \mathrm{C}$ に冷却して成形した. 成形後 5分間保持した後抜き出した. Photo. 4 は成形体を 抜き出した直後の写真である. 凍結した成形体が破 損することなく突出しピンにより抜き出されている.

この成形体を室内に放置し自然乾燥させた後焼結 したものをPhoto. 5 に示す. フランジ部に亀裂発生 が認められるが, この亀裂は自然乾燥中に生じたも のが，焼結時にやや拡大したものである.

\section{6 結 論}

複雑形状を有する厚物ファインセラミックス部品 のための粉末成形法として, 水バインダを用いる凍 結圧縮成形法を提案し, その成形が可能であること を明らかとした．得られた結果を以下に列挙する.

(1)ファインセラミックス粉末は水のみの添加によ っても良好な流動性を示す.

(2)水添加 $20 \mathrm{wt} \%$ （50vol\%）以下でも成形体の密 度は, 粉末射出成形やスリップキャスティングと同 等の密度が得られる.

(3)圧縮後凍結された成形体は, 突出しピンにより 成形体の形状を崩すことがなく取出すことが可能で あった.

(4)複雑形状成形体の乾燥収縮によるクラック発生 は凍結真空乾燥法によって防ぐことが可能であり, かつ乾燥時間が短い。

また成形実験の結果に明らかとなった問題点とし ては, 水バインダを使用しているため, 樹脂バイン ダと比較して, 粉末が型表面へ直接接触することに より, 型摩耗が激しいと予想される点がある.これ に対しては, 水の量を多くして成形圧を下げる方法 や, 凍結時の膨張により圧力が上昇することを考慮 して, 成形後加圧力を抜くことも必要かと思われる。 耐摩耗性があってかつ熱伝導が良く機械加工の容易 な型材が見付からないのが難点である. また凍結時 間が長いのも難点であり, 特に厚肉となると問題が 大きいが, この場合は形状が単純であれば周囲が固 まった時点で取出すことも可能かと考えられる.さ

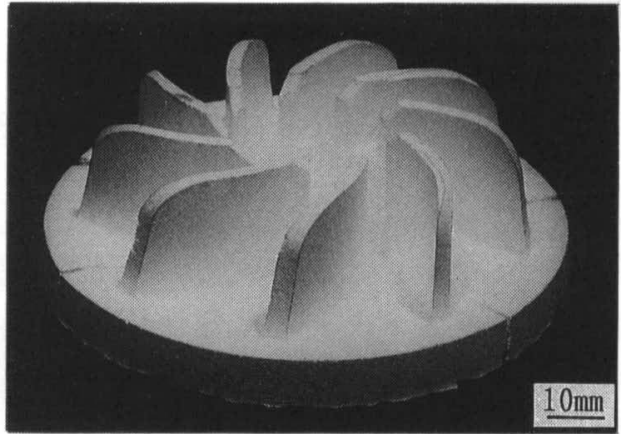

Photo.5 After netural drying sintered $f$ in specimen.

らに, 乾燥収縮に伴うクラックについては, 恐らく 水溶性の有機バインダを少量混入することにより, かなり防げる可能性が高く, 必ずしも凍結真空乾燥 に頼らなくても済むと思われる。

いずれにしても, 全く新しい成形法を試みに行っ た段階であり，具体的な成形体について，量産して みなければ不明な点が多い.いずれ適当な機会があ れば試みたいと考えている。

\section{謝辞}

本研究を行うに当り, (株)丸七鉄工所, (株)アミ ノ, 三菱商事(株), 大明化学工業(株)のお世話にな った. 厚くお礼申し上げます.

\section{文献}

1) 中川威雄 : 日経ニューマテリアル, セラミック ス製造加工機械特集，7月9日号（1990） 119.

2）石原 守, 加藤宏夫 : セラミックス, 22, №. 5 (1987) 423.

3）斉藤勝義, 寒川喜光, 金子泰成 : 粉体粉末冶金 協会平成 2 年度秋季大会講演概要集, （1990） 170 . 4）中川威雄, 高橋信之, 野口裕之, 張 黎紅: 粉 体及び粉末治金, 34, 9 (1987) 17.

5) T. Nakagawa, L. Zhang, H. Noguchi, N. Takah ashi, K. Suzuki : Modern Developments in Powder Metallurgy, 20 (1988. 6) 763. 